\title{
The Strange Fruit of the Tree of Liberty: Lynch Law and Popular Sovereignty in the United States
}

\author{
Michael Gorup
}

\begin{abstract}
Lynch mobs regularly called on the language of popular sovereignty in their efforts to authorize lynchings, arguing that, as representatives of the people, they retained the right to wield public violence against persons they deemed beyond the protections of due process. Despite political theorists' renewed interest in popular sovereignty, scholars have not accounted for this sordid history in their genealogies of modern democracy and popular constituent power. I remedy this omission, arguing that spectacle lynchings—ones that occurred in front of large crowds, sometimes numbering in the thousands_-operated as public rituals of racialized people-making. In the wake of Reconstruction, when the boundaries of the polity were deeply contested, spectacle lynchings played a constitutive role in affirming and circulating the notion that the sovereign people were white, and that African Americans were their social subordinates.
\end{abstract}

$\square$ etween 1877 and 1950, white mobs across the American South lynched 4,075 African Americans-more than one person per week for seventy-three years (Equal Justice Initiative 2017). In their attempts to authorize these acts of extra-judicial execution, lynch mobs called on the language of popular sovereignty, arguing that, as representatives of the people, they retained the right to wield public violence against individuals they deemed to be beyond the protections of due process. Indeed, the term lynching was historically and semantically bound to the idea of popular authorization. As the historian Christopher Waldrep has observed, for much of American history, "plausibly calling something a lynching compellingly argue[d] that the violence had popular support" (Waldrep 2002, 8). James Elbert Cutler, who produced the first scholarly monograph on lynching while it was still ravaging the American South in 1905, placed the issue of popular authorization center-stage: "it is not too much to say," he wrote, "that popular justification is the sine qua non of lynching. It is this fact that distinguishes lynching, on the one hand, from assassination and murder, and, on the other hand, from insurrection and open warfare" (Cutler 1905, 276). In other words, prior to the sustained campaigns of antilynching activists such as Frederick Douglass, Ida B. Wells, T. Thomas Fortune, and W.E.B. Du Bois, "lynching" signified popular legitimation beyond the law.

Popular sovereignty did not serve an exclusively justificatory role, however. In this article, I examine public spectacle lynchings as rituals of people-making. Lynchings were, to be sure, acts of terror instrumental to securing white social dominance in the aftermath of emancipation. But this was not their only political function. As elaborate public rituals, mass spectacle lynchings-ones that occurred in front of large crowds, sometimes numbering in excess of ten-thousand people-played a constitutive role in affirming and circulating the notion that the sovereign people were white, and that African Americans were their social subordinates.

Michael Gorup (1) is Assistant Professor of Political Science at New College of Florida (mgorup@ncf.edu). His writing has previously appeared in the journals Law, Culture, and the Humanities and Political Science Quarterly. He is currently writing a book on race and the politics of peoplehood in the history of American political thought.

Previous versions of this paper were presented at the University of Virginia, New College of Florida, and the 2018 annual meetings of the American Political Science Association and Association for Political Theory. Thanks to audiences at those events for comments, as well as Barbara Arneil, Lawrie Balfour, Jason Frank, Rafael Khachaturian, Hagar Kotef, Isaac Kramnick, Alexander Livingston, and Aziz Rana for feedback and guidance on earlier drafts. Gratitude is also due to Daniel O'Neill for excellent editorial direction and to four anonymous reviewers for insightful comments. Lastly, a special note of appreciation is owed to Billie Holiday, whose moving rendition of the song "Strange Fruit" inspired the paper's title. This article is dedicated to the memory of Isaac Kramnick. 
Existing scholarship has predominantly analyzed lynching in instrumental terms, as either a tool of racial terror or a means for pursuing a particular conception of justice (i.e., 'rough justice,' 'popular justice,' [Berg 2015; Brundage 1993; Epperly et al. 2019; Kirkpatrick 2008; Pfeifer 2006; Tolnay and Beck 1995]). Some scholars have looked closely at the performative and ritualistic dimensions of spectacle lynching but have emphasized its religious meaning — as a racialized practice of human sacrifice-rather than its specific political significance (Mathews 2002, 2017; Patterson 1999; Wood 2011). And when lynching has been examined as a political ritual, popular sovereignty has not been seen as an integral component (Belew 2014; Buckser 1992; Clarke 1998; Garland 2005; Hale 1999; Smångs 2016). Rather, popular sovereignty has typically been understood as a rhetorical device that lynch mobs deployed to legitimate their disregard for legal procedure. I propose a novel theoretical framework for understanding spectacle lynching as a ritual of racialized people-making. As Michel Foucault has suggested, public executions have never simply been scenes for dispensing justice, but always belong "to the ceremonies by which power is manifested" (Foucault 1995, 47). In spectacle lynching, the people-usually a theoretical abstraction - was imagined to appear as a concrete reality, manifesting their power through the exercise of extraordinary violence. ${ }^{1}$ The violence of spectacle lynchings should thus be understood as a performative violence that made manifest the very people in whose name it was said to be authorized (Euben 2017). Lynchings were certainly scenes of subjection (Hartman 1997), but they were also scenes of constitution. ${ }^{2}$ In the wake of Reconstruction, at a moment when the boundaries of the polity were deeply contestedwhen the people were emphatically not at one with themselves-lynching intervened to manifest the political body of the people in the form of a racialized social body. Lynching terror was thus not only of instrumental value in securing white rule but was constitutive of the very foundations of the Jim Crow order.

Despite the centrality of the notion of popular sovereignty to lynching, the scholarly literature on popular sovereignty provides few avenues for grasping its political legacy. The concept of popular sovereignty has in recent years emerged as a central preoccupation for scholars working in democratic theory and the history of political thought. Historians of political thought have carefully traced the concept's origins and firmly established it as the cornerstone of modern theories of democracy — even challenging the primacy traditionally placed upon its common accomplice, political representation (Bourke and Skinner 2017; Lee 2016; Morgan 1989; Tuck 2016). Normative theorists of democracy have interrogated the relationship between popular sovereignty, on the one hand, and individual rights and the rule of law, on the other (Habermas 1994; Honig 2007; Kalyvas 2005). One persistent area of debate has concerned the composition of the people (commonly known as the "boundary problem"): if modern democratic thought posits that all legitimate authority must be derived from the people, how might it be decided who legitimately counts as a member (Abizadeh 2012; Canovan 2005; Espejo 2011; Frank 2010; Näsström 2007)? Our democratic reflexes would instruct us to refer this matter to the people themselves, but there is no principle, rule, or procedure that they-whoever "they" might be, which is precisely the problem to be addressed - can appeal to without controversy to decide who is included and who is left out. Positing the people as the final ground of public authority therefore generates a problem of infinite regress with which democratic politics must grapple but that it can never decisively resolve.

In other words, the people is not an empirically given entity. Rather, each claim to speak in the people's name-whether explicitly articulated as such or implicitly suggested by the appearance of bodies assembled together in public-enacts the people anew (though never ex nibilo; Frank 2010). This means that the identity and composition of the people remains an intractable site of political conflict; and this conflict necessarily extends beyond the formal limits of institutional politics, manifesting in the form of street protests, marches, demonstrations, and spontaneous episodes of popular assembly. For the most part, democratic theorists have suggested that such conflict has been salutary-generating agonistic (rather than antagonistic) struggles over the scope and form of the polity, and ultimately leading to an expansion of the horizons of freedom and equality. ${ }^{3}$ Even if, as Bonnie Honig remarks, "the people... are always inhabited by the multitude, their unruly ungovernable double" (Honig 2011, 3), democratic theorists have mostly been reluctant to interrogate what might be called the 'dark side' of popular politics: its violent, nativist, and racist manifestations. Kevin Olson has accordingly raised the suspicion that democratic theorists have imparted an unjustified presumption of "rectitude" to "popular mobilizations and insurgencies," leading "to an uncritical romanticization of popular politics" (Olson 2016, 8). Beyond the normative concerns flagged by Olson, this presumption furthermore undermines our ability to generate critical insights about how and why reactionary political formations have so often donned a "popular" garb. This should be particularly worrisome given the groundswells of the present-a moment during which authoritarian projects are increasingly waged in the name of the people. ${ }^{4}$

I remedy this omission by offering a critical analysis of the role that the rhetoric and aesthetics of popular sovereignty played in Jim Crow era lynchings. Despite popular sovereignty's undeniable revolutionary credentials, a complete account of its legacy requires a candid reckoning with 
its place in the conceptual toolbox of counterrevolution (typically understood as its antithesis; Bonner 2009, Wilson 2013). While it is beyond this article's scope to provide an exhaustive catalogue of the variety of counterrevolutionary purposes to which popular sovereignty has been summoned, analyzing the case of spectacle lynching brings at least one into clear view: the revanchist aim of re-founding the demos as an exclusivist-and, more specifically, a racialized — political body. As Claude Lefort has argued in a different context, the people emerge with distinctive clarity when their enemy has been identified and marked for violence. It is this logic — which Lefort calls the logic of the "purge" - that underlay the ritual character of lynching (Lefort 1991, 84). In the wake of Reconstruction, when the racial boundaries of the polity were thrown into profound question, spectacle lynchings sought to suture the people's (racialized) body through the ritual performance of violent expulsion.

My argument builds on a growing body of literature that has aimed to recover and amplify the distinctive theoretical contributions of black political thinkers. While the tradition of black political thought-like all robust intellectual traditions - speaks with many voices, scholars have drawn on authors in this tradition to shed light on the foundational role that anti-black oppression has played in the formation of Euro-American modernity (Hanchard 2010; Mills 1999; Olson 2004), urging theorists to rethink many of the central categories of Western political thought. In the U.S. context, much of this work has focused on the relationship between democracy and race (Balfour 2011; Bromell 2013; Turner 2012), and some has addressed the question of peoplehood (Allen 2006; Frank 2010; Rogers 2012). However, scholars have yet to fully explore the practices by which racialized peoplehood has been constituted and sustained. Building on this literature, I show how spectacle lynching played an integral role in founding and reproducing the white demos of the Jim Crow imaginary. Drawing on the political thought of Ida B. Wells, as well as of Frederick Douglass and W.E.B. Du Bois, I theorize lynching as a distinctive exercise of popular constituent power-one that aimed not to create or alter legal institutions, but to police the boundaries of who can plausibly claim to belong to the political community.

\section{The History of Lynch Law}

Most historians cite Charles Lynch of Bedford County, VA as the eponymous source for the phrase "Lynch Law," which originally took the possessive form "Lynch's Law," and subsequently derived into the verb "to lynch" and the gerund "lynching"' (Dray 2003, 21; Rushdy 2014, 23-24; Waldrep 2002, 15-20). Lynch led the Bedford County militia during the Revolutionary 1780s and hosted an informal court that punished alleged insurgent Tories in the western part of the state of Virginia, typically via flogging and hanging. Then-Governor Thomas Jefferson wrote to Lynch during the war to offer some cautious praise for his brand of rough justice, applauding him for "seizing" the dangerous Loyalists but simultaneously admonishing Lynch that he "take care" that those he deemed guilty be sent to Richmond to "be regularly tried afterward" (Waldrep 2002, 17). Lynch ignored Jefferson's plea for due process - apparently satisfied with the legitimacy of the system of justice he and his fellows had crafted. One of Lynch's militiamen had noted that, despite some procedural irregularities, each hanging was ultimately authorized by "the joint consent of near three hundred men" (Rushdy 2014, 23). Popular consent was of course central to the language of democratic legitimacy as it was then developing in revolutionary America - perhaps most conspicuously in Jefferson's pronouncement in the Declaration of Independence that governments derive "their just powers from the consent of the governed." Furthermore, the right to punish was often considered by early modern political thinkers-such as Jefferson's intellectual precursor John Locke-as the foundational "just power" that civil government was founded to administer. Given the exigencies of the war, Lynch and his militia took it to be within their legitimate power as settlers and citizens to exercise this fundamental right in the absence of effective civil authority. And at the war's end, Lynchwho was a legislator in the Virginia General Assemblysuccessfully sought indemnity from the state government for his actions, a gesture that would stamp his extra-legal usurpation of the right to punish with retrospective validity.

By 1782, Lynch began to speak of "Lynch's Law" when describing his brand of popular justice. The term spread relatively quickly afterward, but it did not immediately eclipse other terms for referring to vigilante violence; nor would it appear regularly in print until several decades into the nineteenth century. Most of the acts described as lynchings during the antebellum period were violent and cruel, but predominantly non-lethal, such as tarring and feathering, flogging, and other forms of violent intimidation (Rushdy 2014, 29-30). And despite the pervasiveness of popular violence-particularly during the Jacksonian era-comparatively little of it was performed for the purpose of securing racial hierarchy.

The public murder of enslaved persons in the antebellum South was rare by comparison to the horrifying frequency of racial lynchings during Jim Crow. Enslaved people were considered property, and as such their bodily integrity bore a market value. If a mob were to publicly abuse or murder an enslaved person, they would be directly interfering with the property rights of a white slaveholder. However, antebellum racial hierarchy-founded upon the forcible expropriation of labor-was nevertheless maintained and reproduced through violence. Part of this violence was exercised by the state: the catalogue of crimes for which a black defendant 
could be executed in most Southern states was far more numerous than for whites. Moreover, African-Americans were liable to be subject to more brutal forms of execution, such as burning at the stake-though such grisly violence was typically reserved for extraordinary accusations, such as plotting an insurrection (Kaufman Osborn 2006, 39). The bulk of the violence that sustained racial hierarchy in the Old South was exercised by slaveholders and their appointed overseers, who were afforded near-unlimited discretion when it came to the physical force they could visit upon enslaved persons. To the extent that the overseers of the plantation regime effectively kept enslaved persons at bay, lynching was a redundant tool of social control.

During Reconstruction, lynching emerged as a distinctly racialized practice. Extra-legal racial violence was an essential component of the repertoires of resistance employed by Redeemers during the 1860s and 1870s, who sought to reassert white control in the wake of emancipation. This violence was mostly carried out by clandestinely organized groups_ — such as the first Ku Klux Klan, the Red Shirts in Mississippi, and the White League in Louisiana-that anticipated the terrorist organizations of the Jim Crow era (and who were themselves anticipated by antebellum slave patrols). Antebellum racial hierarchy had been sustained through a network of institutionsthe prerogatives afforded to slaveholders and overseers, draconian legal codes, and slave patrols - that were swiftly eliminated by the Reconstruction amendments and subsequent Civil Rights Acts. Lynching thus began to emerge as an operative tool for restoring the hierarchies of the Old South in the absence of the slave regime, setting the stage for the role it would so infamously fill during Jim Crow (Pfeifer 2006, 14). If white landowners wished to maintain the status and streams of profit they enjoyed during the antebellum period, it would be necessary to reinforce the racial hierarchies that had long undergirded the plantation system through new means.

However, lynching was also more than an enforcement mechanism for racial hierarchy. Public spectacle lynchings performed the integral political work of symbolically repudiating the achievements-however fraught they may have been-of the Civil War and Reconstruction, ultimately laying the foundations for a new regime of white supremacy. In Black Reconstruction, W.E.B. Du Bois famously described Reconstruction as a "splendid failure": a failure because it never fully transformed American democracy in the ways that its most radical adherents had aspired, but a splendid one because it did not fail in the ways that the Southern ruling class had predictedand hoped-it would (Du Bois 1998 [1935], 708). Reconstruction failed not because emancipation had been too rapid or thoroughgoing, but because it was overthrown at the hands of the still-regnant Southern plantocracy. Indeed, as Du Bois showed, it was African Americans' astonishing success as freedmen and citizens that ultimately spurred the counterrevolutionary mobilization that would end Reconstruction.

The political legacy of Reconstruction is most often associated with the dramatic legal and institutional changes enacted between 1860 and 1877: the wartime expansion of executive power and the peacetime consolidation of federal authority; the ratification of the Thirteenth, Fourteenth, and Fifteenth Amendments; the adoption of new state constitutions across the former Confederacy; and congressional extension of civil rights. To be sure, many of these achievements were successively weakened — and in some cases altogether jettisoned_-even before Reconstruction formally came to a close with the Compromise of 1877, after which the former Confederate states would gradually reinstitute de jure white supremacy for the next several decades. But this familiar narrative of institutional expansion and retrenchment tends to obscure another, perhaps more profound, dimension of Reconstruction's legacy. As Du Bois lamented, "the unending tragedy of Reconstruction is the utter inability of the American mind to grasp its real significance, its national and worldwide implications." Its "real significance," according to the Du Bois of the tumultuous 1930s, lay in its revolutionary meaning as an event "comparable to the upheavals in France in the past, and in Russia, Spain, India and China today." As Du Bois saw it, and as figures like Charles Sumner and Thaddeus Stevens fought for it, Reconstruction was nothing less than an effort to reconstitute "the very foundations of democracy" in the United States (Du Bois 1998, 624). It was a project that aimed not only at reconfiguring political institutions and redistributing political power, but at re-founding the demos as a multiracial political body.

With the overthrow of Reconstruction, the Redeemers had to formulate a strategy for reinstituting white supremacy amid the transformed terrain wrought by Union victory. This meant grappling with, and where possible peeling back, the aforementioned institutional reforms; but it also required confronting the political imaginary of what Du Bois called the "abolition-democracy" - that is, the robust vision of emancipation and multiracial democracy that had driven Radical Reconstruction. The stunning example of black citizenship that Reconstruction unleashed upon the world-stage-the very essence of its "splendidness"-ensured that in the following decades ambiguity would remain about who could legitimately claim membership in the polity. As such, in addition to taking the reins of institutional power, the Redeemers had to restore the racialized underpinnings that had given "the people" coherence and form in the antebellum imaginary. Public spectacle lynching would emerge as a political ritual to fill precisely this role. However, before further unpacking this argument, it is first necessary to situate lynching within the broader social landscape of Jim Crow. 


\section{Lynching and Jim Crow Domination}

Despite the noted differences in how violence was organized and deployed during slavery and Jim Crow, there are nonetheless important parallels connecting the two eras. Indeed, many of Jim Crow's most incisive analysts and trenchant critics —including Douglass, Wells, and Du Bois-made regular note of the striking continuities between that period and the slave regime that had preceded it. Du Bois memorably described the narrative arc of emancipation, Reconstruction, and Redemption as one in which "the slave went free; stood a brief moment in the sun; then moved back again towards slavery" (Du Bois 1998, 30). Wells formulated the point even more strongly. Jim Crow, she astonishingly wrote, is merely the tyranny of slavery "at work under a new name and guise ... The very same forces are at work now as then. The attempt is being made to subject to a condition of civil and industrial dependence, those whom the Constitution declares to be free men" (Wells 2014, 111, emphasis original). These words should elicit even more astonishment once it is recalled that they were penned by a woman who was born into slavery. Notwithstanding the achievements of emancipation and Reconstruction, Wells contended that "the very same forces are at work" in the 1890s as under slavery, disenfranchising, impoverishing, and terrorizing the black community into a condition of dependence and unfreedom on par with enslavement.

Wells' claim was partially intended to rhetorically provoke the reader, and it is worth noting that elsewhere in her writings she acknowledged some important differences between slavery and Jim Crow. However, the claim was nonetheless based upon an important analytical insight. Slavery, as republican thinkers have commonly observed, is a relationship of domination defined by the discretionthat is, the arbitrary power of interference-afforded to the slaveholder over the activities of the enslaved (Pettit 1999; Skinner 2012). ${ }^{6}$ Less fully appreciated by many republican thinkers is the fact that, under slavery, this discretion can be taken to its mortal limit: as a property owner, the slaveholder always retains the right to "dispose" of an enslaved person's life with impunity. Orlando Patterson has accordingly described slavery as a "conditional commutation," a mode of subjugation defined by the deferment of execution "as long as the slave acquiesced in his powerlessness" (Patterson 1982, 5). The social death of slavery, in other words, is defined by the latent potential for physical death.

According to Wells, it is on this point that Jim Crow domination is structurally homologous to slavery. Her argument is not merely the familiar neo-republican one that all forms of domination are "paradigmatically exemplified by slavery" (Pettit 1996, 577) and thus, as an instance of domination, Jim Crow exhibits features akin to slavery (namely, that black people are continuously vulnerable to interference by whites, e.g., GoodingWilliams 2011, 168-76). Rather, for Wells, the connection runs much deeper: like slavery, Jim Crow is a condition of severe personal domination in which all whites take it to be "their right to rule black men" (Wells 2014, 111). This presumptive right to rule-expressed, at its definitive limit, via killing - is a direct inheritance from slavery, "the inevitable result of unbridled power exercised for two and a half centuries, by the white man over the Negro" (Wells 2014, 221). Under Jim Crow, it is therefore not merely the case that whites may capriciously interfere with black persons' activities, but that they may arbitrarily decide to use lethal violence. The open possibility of violent death inflicted with impunity is, according to Wells, the condition that defines both slavery and Jim Crow as twin modes of domination.

On Wells' analysis, lynching should be counted among the defining institutions of Jim Crow society. In its extraordinary violence, it defined a political ordinary: terror and submission for African Americans, sovereignty and honor for whites. As she powerfully explained in 1900 , lynching "is not the creature of an hour, the sudden outburst of uncontrolled fury, or the unspeakable brutality of an insane mob. It represents the cool, calculating deliberation of intelligent people who openly avow that there is an "unwritten law" that justifies them in putting human beings to death without complaint under oath, without trial by jury, without opportunity to make defense, and without right of appeal" (Wells 2014, 394). Wells situated the practice of lynching firmly within the national civic culture-anchored in what Balfour (2015, 685) refers to as the American "shadow constitution." She in turn discredited excuses for lynching that depicted it as the spontaneous, impassioned response of a local (white) community to a shocking episode of social transgression. Rather, she showed lynching to be a deliberate tool of social subordination.

Jim Crow white supremacy depended upon enlisting ordinary whites in the task of enforcing the color line, with lynching defining one end of the spectrum of available methods of enforcement. As C. Vann Woodward argued in his seminal 1955 study of the era, "the Jim Crow laws put the authority of the state or city in the voice of the street-car conductor, the railway brakeman, the bus driver, the theater usher, and also into the voice of the hoodlum of the public parks and playgrounds. They gave free rein and the majesty of the law to mass aggressions that might otherwise have been curbed, blunted, or deflected" (Woodward 2001, 107). Lynching thus operated in ways that were both consistent with and complementary to the segregationist state legal regimes with which Jim Crow is today held to be synonymous. "Whenever a malicious law is violated in any of its parts," Wells wrote in 1893 (in a passage that must have caught Woodward's eye), "any farmer, any railroad conductor, or merchant can call together a posse of his 
neighbors and punish even with death the black man who resists and the legal authorities sanction what is done by failing to prosecute and punish the murderers" (Wells 2014, 111). In other words, Jim Crow effectively deputized all white persons to act with sovereign authority to violently enforce the legal codes and social norms that upheld the racial order.

Wells regularly described black life under Jim Crow as subject to a regime of "lawlessness." For political theorists, this language might evoke familiar discourses of emergency and exception, commonly associated with the work of Carl Schmitt and Giorgio Agamben. According to Schmitt, a state of exception ensues when the sovereign suspends the rules that structure the ordinary legal order-a decision undertaken often, though not necessarily, in response to some real or perceived emergency (Schmitt 2006). Lynching, with its invocation of the revolutionary language of popular sovereignty and its flagrant disregard for due process, has often appeared temptingly like a paradigmatic example of a democratic exception: a moment in which the sovereign people call forth a temporary interruption in ordinary legal procedure to punish an enemy deemed beyond the protections of the law (Carr 2016; Friedman 2007; Mbembé 2003; McKnight 2013; Squires 2015). Indeed, the political ideology of lynching lends evidence to this suspicion. In the words of the prominent Georgia politician Thomas E. Watson, "Democracy means, that ALL POWER IS IN THE PEOPLE! The right to establish government, choose rulers, make laws, found institutions, reward merit, and punish crime, is in the People. The People delegate these powers, but never surrender them ... Just like any other principal who appoints an agent, and is betrayed by that agent, the People may ignore the act of a recreant agent, and do FOR THEMSELVES what the agent failed to do" (Waldrep 2006, 195). Watson's seemingly crude definition of democracy resonates with Schmitt's, who claimed that the "essence of the democratic principle" is the "assertion" of "an identity between law and the people's will" (Schmitt 1988, 26). ${ }^{8}$ Schmitt, like Watson, was likewise concerned about the possibility that state institutions may usurp their democratic mandate by failing to embody the people's will, thus engendering a crisis that creates an opportunity for the people-or, more realistically, some minority claiming to be the people-to take the reins of power themselves. Watson depicts lynching to emerge out of this precise set of circumstances: it is the people reclaiming their primordial right to wield sovereign violence - an action necessitated by the morass of judicial procedure, which serves only to thwart the popular will by affording the accused with too many protections. "The Sheriff gets his authority to hang a man from the Law, but the Law got it from the People," states Watson. "Therefore, the power remains in the People, who have only delegated it to an agent" (Waldrep 2006, 195).
However, Wells' emphasis on the essential "lawlessness" of the Jim Crow regime cannot be adequately comprehended through the logic of exception, understood as either a Schmittian legal vacuum or, as Agamben describes it, a "zone of indifference," "a violence without logos" (Agamben 2005). Lynching was neither the outcome of a paucity of legal authority, nor the consequence of the law's temporary suspension, but was, in Wells" words, "in force . .. in some of the oldest states of the Union, where courts of justice have long been established, whose laws are executed by white Americans. It flourishes most largely in the states which foster the convict lease system, and is brought to bear mainly, against the Negro" (Wells 2014, 133). Lynching did not signal a momentary interruption in the legal order but, rather, law's selective application to African Americans. Jim Crow white supremacy effectively rendered black people's legal standing dependent upon whites' discretion: when convenient, it would be upheld; when an impediment to white purposes, it could be ignored. The "lawlessness" of lynching, according to Wells, worked in tandem with segregationist state codes and legal institutions-the police, the courts, and the punitive apparatus - to uphold white supremacy. Indeed, those who lynched often took themselves to be the guardians of the legal order, arguing that the protections of due process and the leniency of the courts tended to "rob the law of part of its terror," which they sought to reinstate through episodic popular violence (MacLean 1991, 944). While they might have wished to ignore some federal statutes-especially key clauses of the Reconstruction Amendments - there nonetheless existed an ensemble of state and local laws that directly abetted the segregationist cause; a cause that was further aided by the connivance (and often outright support) of state and local law enforcement. ${ }^{9}$ Therefore, rather than modeling the exceptional politics theorized by Schmitt or Agamben, Well's analysis more closely tracked Walter Benjamin's well-known dictum that "the tradition of the oppressed teaches us that the 'state of emergency' in which we live is not the exception but the rule" (Benjamin 2019, 200). Lynching represented a species of "lawlessness" internal to American racial democracy, not an exception at its limits.

Defenders of lynching like Watson tended to frame it as a practice in which the popular will momentarily prevailed over the law-a sovereign exception, or an instance of what Benjamin called "lawmaking violence." Alternatively, some apologists depicted lynching as the law's fulfillment (as implied in the common appellation "Lynch Law"), which might instead be understood as a variety of "law-preserving violence" (Benjamin 1986, 287). "The people," explained one defender of lynching, "are a law unto themselves and the spontaneous action of the outraged community has all the effect of legal enactment. The people make the law; they are the governing power; and when an unnatural crime for which no proper punishment 
is provided, occurs in any community, the people of that section have the right to supply the omission and prescribe the adequate redress" (Pleasant 1893, 100). While the difference between these two conceptions may at first seem significant, both perspectives frame the central question in terms of legality and in turn overlook the political work that lynching performed. Therefore, rather than interrogating the basis of lynching's normative justification (or lack thereof [Kirkpatrick 2008]), I suggest we instead attend to the political productivity of the violence itself (Valdez 2020). On the view developed here, lynching is best understood as a form of what Benjamin termed "mythic violence" - a violence that at once subtends and sustains the legal order (Benjamin 1986, 294-95). As the next section will show, lynching operated on a register logically prior to law, as the staging and enactment of the vision of popular authority that anchored the Jim Crow imaginary.

\section{Lynching as Political Ritual}

On February 1, 1893, Henry Smith was publicly murdered before a crowd of several thousand people in his hometown of Paris, Texas. He had been accused of raping and murdering the daughter of a local sheriff's deputy. Smith was first paraded around the town square several times atop a cotton float, "in mockery of a king on his throne" (Dray 2003, 78), before being fastened to a scaffold conspicuously emblazoned with the word "Justice!" He was then tortured with hot irons for nearly an hour by the deputy and his family before the scaffold was doused in oil and set ablaze by members of the crowd. Still alive, Smith launched himself off of the platform in an attempt to escape the flames, but he was repeatedly pushed back into the fire by the crowd and eventually held down by a rope around his neck until he died. By the time the fire burned out, all that remained was a heap of ash and bone that spectators eagerly picked through in the hopes of gathering mementoes.

Smith's brutal murder was at the time an extraordinary event. Many of those in attendance had arrived via specially arranged trains from across Texas and neighboring Arkansas. The lynching received extensive coverage in both regional and national newspapers, with images and sound recordings reportedly being displayed in locations as distant as the streets of Seattle and a theater in New York (Wood 2011, 72-74). In 1895, Wells remarked that in lynching Smith, the white community of Paris had "inaugurate[d] an entirely new form of punishment" (Wells 2014, 240-241). During the next several decades, however, the rites and repertoires that accompanied Smith's murder would be self-consciously replicated across the American South. Though racial violence was by no means new or unfamiliar, Smith's murder marked the dawn of an era during which highly publicized acts of racial violence-mass spectacle lynchings—occurred with horrifying regularity. Smith's death has accordingly been described as "the founding event in the history of spectacle lynchings" (Hale 1999).

Orlando Patterson estimates that just over a third of all Jim Crow lynchings involved a crowd of fifty or more persons - in some cases, like Smith's, numbering as high as several thousand. These were lynchings that tended to bear clear symbolic markings, including the careful selection and curation of the lynching site (often the scene of the alleged crime), the use of exceptionally gruesome methods of torture (dismemberment, castration, immolation), and the collection of keepsakes from the lynching scene by members of the crowd (most appallingly, pieces of the victim's body; Patterson 1999, 179). Images of such ghastly scenes of execution sometimes appeared on postcards, accompanied by chillingly banal messages intended for the recipient friend or family member (Allen 2000). Spectacle lynchings also tended to follow a recognizable narrative arc that incorporated some of the conventions of state-sanctioned public executions-dramatic condemnatory speeches by the mob's leaders, the forcible extraction of a confession, and, with the onset of torture, pleas for mercy by the victim (Wood 2011). At a spectacle lynching, however, the crowd was never merely a passive audience: they were always active participants in the violence. On one level, simply by bearing witness - and thereby lending legitimacy - to an act of extra-legal violence, the crowd always bore some degree of responsibility for the brutality. But, more significantly, most lynchings had no clear demarcation between participant and spectator. Even when lynch mobs had recognizable leaders, members of the crowd would still freely participate in the violence-shooting, cutting, or otherwise maiming the victim's body. Sometimes the method of death would even be decided by popular vote among those assembled (Garland 2005, 805). Spectacle lynchings were therefore always distinctly collective acts of violence.

Take, for instance, the lynching of Sam Hose in 1899one of the most infamous murders of the era. Hose, a resident of Coweta County, Georgia, was accused of killing his white employer amid a dispute over wages. He was apprehended a few days later and promptly bound to a sapling, around which gathered an estimated crowd of two thousand. According to the Atlanta Constitution, which had been demanding Hose's death over the preceding week, "the stake was in full view of those who stood about and with unfeigned satisfaction saw the Negro meet his death." As was typical, Hose was stripped of his clothing and tortured by the crowd: first his ears were cut off, and then "other portions of his body were mutilated by the knives of those who gathered about him." After a forced confession, he was finally burned alive. As with the killing of Henry Smith, the crowd was eager to collect mementoes and afterwards "persons were seen walking through the streets carrying bones in their hands" 
(Wells 2014, 324-325). Hose's knuckles were later put on display for sale at a local grocery store, a happening that famously prompted the young Du Bois to reconsider his conviction that racism could be explained by ignorance (Du Bois 2014). Those who attended Hose's death made no attempt to hide the gruesome facts of the lynching or conceal the identities of those involved. A detective hired by black Chicagoans to investigate the murder easily secured interviews with participants, who "discussed the details of the burning . . . with the freedom which one would talk about an afternoon's divertissement in which he had very pleasantly participated" (Wells 2014, 328). And yet, as was typical, no one was found guilty in a court of law. In the event that there was a legal investigation into a lynching, the typical outcome was the discovery of death "at the hands of persons unknown."

The publicity of spectacle lynchings accounted for much of their political power. The public display of extraordinary violence exerted on a victim's body carried a symbolic force, aimed at an extended audience of witnesses and readers, both black and white. For the black community, lynchings were acts of terror designed to dramatize their subordinate status and elicit the submission demanded by Jim Crow ideology. Lynchings would often deliberately involve methods of torture that had been used to punish enslaved persons prior to emancipationsuch as whipping, castration, and the severing of ears (Dray 2003, 30, 43). In wielding these methods, lynch mobs would effectively stage an encounter that was visibly reminiscent of a slaveholder securing the submission of an enslaved person through bodily violence. Lynchings, of course, bore the important difference of almost always ending in the person's death, which carried a resonance of its own. As Richard Wright recalled of his youth in 1945 , "I had never in my life been abused by whites, but I had already become conditioned to their existence as though I had been the victim of a thousand lynchings." The nagging awareness of the ever-present possibility of lethal violence shaped his daily conduct: "the penalty of death awaited me if I made a false move and I wondered if it was worth-while to make any move at all" (Wright 2007, 65). This is a familiar though nonetheless significant point: lynching was a tool of terror designed to thwart black political mobilization. As Wells had argued, the lesson of lynching for African-Americans was always "the lesson of subordination" (Wells 2014, 75).

But this was not lynching's only function. As Foucault has argued, the public execution should be understood not merely as a "judicial but also a political ritual" (Foucault 1995, 47). Public executions have never simply been instruments of social control but have always been bound up with the constitution of political authority. Public violence, on this understanding, is not simply wielded on the basis of sovereign authority: it is integral to the production of sovereignty as a political form. Building on this insight, we can see that lynchings were generative political rituals that - in their very performance-shored up social hierarchies and enacted a racialized vision of the demos. Defying Foucault's neat chronological separation of sovereign and biopower, lynchings are better understood as "disciplinary spectacles" that simultaneously shaped individual conduct and constituted public authority (Brendese 2017). Wells recounts a lone dissenting witness to the Smith lynching who pleaded that parents "send the children home" in order to spare them the sight of the grisly spectacle. To this "a hundred maddened voices" replied: "no, no ... let them learn a lesson" (Wells 2014, 246). As Wells explained, the violence on display was designed to be politically instructive about the regime of white supremacy and the social roles it designated. In calling together a mass of spectators and participants to the scene of extra-legal violence, the rituals of lynching interpellated white crowds, providing them with a sense of their power, unity, and honor. They thus made Watson's vision of a homogeneous and unitary sovereign people-acting, as one report of the Smith lynching alleged, "with unanimity and by thousands with one voice" (Pleasant 1893, 107)—a palpable historical presence to those assembled.

The ritual character of lynchings has most often been understood as a means of compensating for their illegality. As one scholar has put it, ritual provided "the sense that lynchings were a valid cultural alternative to the criminal justice system" (Pfeifer 2006, 44; see also, Garland 2005, 807-8). Like the label "Lynch Law," the rites that accompanied lynchings were certainly intended to create the impression that the violence exercised bore the stamp of legitimacy; but, as performances of popular power, they also exceeded this purpose. Beyond just bolstering established authority, political rituals carry the power "to create political reality" (Kertzer 1989, 1). As rituals, spectacle lynchings made manifest a distinctive vision of political authority that bound together white self-rule with black subordination. In doing so, they made a counterrevolutionary intervention into the politics of the era-symbolically repudiating the radical legacy of Reconstruction by theatrically staging the social roles and relations of political rule that would compose the emergent Jim Crow order.

Spectacle lynching should be viewed as politically generative along two dimensions: as a ritual of retribution and a ritual of constitution. As a ritual of retribution, spectacle lynching aimed to (re)authorize a regime of white supremacy that perceived itself to be besieged by demonstrating the dramatic inequality between blacks and whites-an inequality made palpable through the public performance of violent domination. It was a ritual that publicly affirmed the centrality and durability of racial hierarchy after the end of slavery. To be sure, lynching was always rationalized as a response to an allegation of crime, but this was not just any crime. The crime in question was always framed in 
distinctly political terms, often as an insurrection against the social order. Thus, akin to Foucault's analysis of the logic of the supplice, lynching was a redemptive violence that, in its very performance, sought to repair white rule. And it did so through the public demonstration of extraordinary cruelty, aiming, as Foucault put it, "not so much to re-establish a balance as to bring into play, at its extreme point, the dissymmetry between the subject who has dared to violate the law and the all-powerful sovereign who displays his strength" (Foucault 1995). Lynching violence was in this sense simultaneously retributive and disproportionate. $^{10}$

The archetypal crime to which lynching responded was, of course, the alleged rape of a white woman by a black man. However, despite its centrality to the ideology of lynching, rape was raised as an accusation in only onethird of the murders that Wells investigated in 1893 (Wells 2014, 134). Recent records suggest an even lower proportion-less than a quarter of all lynchings between 1882 and 1968 followed allegations of rape, half the number connected to allegations of murder (Patterson 1999, 175; Equal Justice Initiative 2017). But rape was nonetheless essential to the mythology of Lynch Law, and not only in the South. In an address to Congress in 1906, then-President Roosevelt affirmed the myth, laying the blame for lynching squarely at the feet of black men, claiming that lynching's "greatest cause... is the perpetration, especially by black men, of the hideous crime of rape" (Roosevelt 1923, 421). Roosevelt's depiction of race as incidental to lynching was, of course, an obfuscation. Rape as such did not incite mob violence. As Frederick Douglass argued in 1892, it is not "the immorality or the enormity of the crime itself that arouses popular wrath, but the emphasis is put upon the race and color of the parties to it ... For two hundred years or more, white men have in the South committed this offence against black women, and the fact has excited little attention." According to Douglass, this "demonstrates that the horror now excited is not for the crime itself, but that it is based upon the reversal of colors in the participants" (Douglass 1892, 19).

Black-on-white rape was imagined to be a total subversion of the hierarchical relationship between the races, violating the sanctity of white womanhood and undermining white men's patriarchal authority. Moreover, it directly threatened the principle of racial segregation - the bedrock of Jim Crow. Turn-of-the-century white supremacy was undergirded by an intricate regime of sexual control, consisting of legal prohibitions against racial mixture in addition to extra-legal acts of terror (Feimster 2011; Hooker 2019). It is no coincidence that, from the 1890 s until the 1920s, scientific racism-particularly Social Darwinism-was at the peak of its intellectual and political influence (McCarthy 2009, 82). From the vantage point of racial pseudoscience, even consensual sex (which Wells contended to be most common) was envisioned as a profound social peril: the "one-drop rule" prescribed that black women could only bear black children, but that white women were uniquely endowed with the ability to bear offspring belonging to either the black or white race. Since racial purity could only be achieved in a society of monoracial families, Jim Crow required the vigilant policing of women's sexuality. Indeed, anti-racist activists sought to challenge anti-miscegenation laws precisely because of their central role in sustaining Jim Crow segregation (Hooker 2019). Violating anti-miscegenation laws was perceived to be more than a mere criminal transgression: it was a trespass against the purity of the people's body. It was for this reason that the myth of interracial rape played an outsized role in the ideology of Lynch Law. As a ritual of retribution, spectacle lynching sought to redeem the social hierarchies that made both patriarchy and white supremacy possible as interlocking forms of social domination (Balfour 2015).

According to Foucault, the regicide was the model criminal under absolutism because in targeting the physical body of the king he or she posed an existential threat to the body politic as a whole; "every crime constituted a rebellion against the law," he explains, and every criminal was construed to be "an enemy of the prince," a regicide in miniature (Foucault 1995, 50). Analogously, the mythic black rapist functioned as the model criminal within the Jim Crow imaginary because in threatening to undermine the racial purity of the people's social body he was imagined to imperil the sovereignty ascribed to the people's political body. ${ }^{11}$ Therefore, in addition to being a ritual of retribution, spectacle lynching was also a ritual of constitution: a practice that staged and enacted the racialized demos in whose name it was said to be authorized. The people, as democratic theory has shown, is not an empirically available entity that exists prior to the institutions that rule in its name. It is instead a political fiction (Morgan 1989). The people is thus more appropriately grasped as the consequence of "popular" politics than its foundation: it is an inexhaustible locus of contestation, iteratively enacted with each claim to popular representation. As noted earlier, democratic theorists have primarily framed this popular "constitutive surplus" (Frank 2010) as a democratic good-a guarantee against the final closure or full juridical containment of democratic politics. However, the people's perpetual openness nonetheless leaves it susceptible to less salutary forms of enactment-ones that take shape through overt acts of violence and oppression, such as lynching. It is in this sense that spectacle lynching can be understood as a ritual of constitution. As collective acts of extra-legal violence legitimated in the people's name, lynchings were episodes in which the Jim Crow vision of the people was made politically manifest. The rites of spectacle lynching enlisted white spectators as participants, facilitating them to see and feel themselves as agents of sovereign violence, and in turn drew a sharp 
boundary between the collective subject of national power and its racialized enemies. Popular agency and identity under Jim Crow were thereby mediated by racial violence (Kotef 2019).

Notwithstanding the protestations of certain abolitionists, race was the linchpin that rendered the otherwise abstract notion of the sovereign people imaginable for much of the antebellum period. This was particularly true as the nineteenth century wore on, as Southern ideologues increasingly invoked notions of racial hierarchy to justify slavery. As Roger Taney would formulate the pointcarrying the force of law-in his infamous 1857 majority opinion for Dred Scott v. Sandford, it was the white race "alone" that "constituted the sovereignty in the Government" (60 U.S. 393 1856). Even if the sometimes-fuzzy boundaries of whiteness never delineated with absolute precision who could be counted among the demos, antebellum racism made it indelibly clear that, at minimum, African Americans were not and could never be included. However, the Civil War and Reconstruction posed a serious challenge- though not an unequivocal defeatto this presumption. Spectacle lynchings constituted one part of a broader political mobilization that responded to the crisis engendered by this challenge. Emerging in tandem with the legal regimes that would come to define Jim Crow, spectacle lynchings sought to reshape national imaginings of the people through the public performance of racialized violence. And recent empirical research provides some evidence to believe that they were at least partially successful in this aim. Smångs (2016) has shown that spectacle lynchings were essential to the formation and consolidation of white solidarity in the Postbellum period. He finds, for instance, that the local incidence of spectacle lynchings between 1890 and 1915 drove Democratic Party support (which by the 1890s was pushing an aggressive program for the renewal of white supremacy). ${ }^{12}$ It is important to note, however, that this was not a simple reprise of antebellum white supremacy: as Wells had shown, Jim Crow generalized the violence of plantation slavery, redistributing the violent agency formerly reserved for slaveholders to white people-claiming the mantle of the people-as a whole. This violent agency was also more murderous than before, as black life had come to be understood as increasingly expendable.

In response to criticism of the Smith lynching, a prominent Texas lawyer argued that the event

but illustrates the theory of our government that all power, at last, resides with and belongs to the people. At times the crime committed is so outrageous and so damnable that the people for a time take back and assume the powers they have delegated and mete out justice sure and swift, and when they do no power on earth . . . can stop them. (Pleasant 1893, 129)

As a reclamation of the people's primordial constituent power, lynching violence was logically, if not temporally, the violence of political founding. It was a mythic violence that gave form not to law or to state institutions, but to the people: by policing the boundaries of the demos, lynching performatively produced the popular sovereign as white. Lynching thereby gave political force to the notion, so essential to the segregationist regime, that the power and vitality of the people's political body was dependent upon its racial purity as a social body.

\section{Conclusion: Lynching's Decline and the Rise of the Carceral State}

Despite the centrality of lynching to Jim Crow, the practice began to fall into decline by the 1930s; and in 1952 the United States would see its first full calendar year without a lynching since the end of Reconstruction. The historical record suggests spectacle lynchings to have declined with even more haste, and to have ceased altogether by the second half of the twentieth century (Dray 2003; Waldrep 2002). To be sure, lynching was almost always cause for public controversy. And, notwithstanding several decades of federal inaction, mass spectacle lynchings in particular had, since Smith's highly publicized murder, regularly attracted alarm and criticism. In 1893, then-Texas Governor Jim Hogg denounced the "mob spirit" that led to Smith's death, which he argued set the state on an inevitable path towards anarchy, "marking the way for the destruction of this Government." Hogg assured his fellow Texans that, for Smith's crime, "the death penalty awaited him under the law," but warned that the proliferation of extra-legal violence would render "legal executions rare and impracticable, if not impossible." Juries would refuse to convict, the most dangerous elements of society would assume a leading role, and the rule of law would come undone (Pleasant 1893, 91, 88-89).

Governor Hogg's condemnation of mob rule was not idiosyncratic. Beginning in the late $19^{\text {th }}$ century, a number of Southern reformers affiliated with the push for a "New South" spoke out against lynching. Many of these reformers were suspicious of popular democracy. Like Hogg, their denunciations of lynching were typically qualified by support for white supremacy: they criticized the unruly white masses they saw to be threatening political order while carefully avoiding coming to the defense of lynching's black victims. They argued that black criminality was the real cause of lynching, and one of the South's most pressing social problems; but it was one that could be more effectively handled by the state's punitive apparatus than the disorderly rabble acting outside the law (Link 1997, 59-63). Indeed, shortly after Smith's lynching, a newspaper editorial cautioned that "the liberation of the negroes will make the Cotton States uninhabitable" so long as white mobs are "willing to descend to the level of the most degraded negro criminals in order to wreak vengeance upon them." It was lawful government, the author affirmed, that elevated white society above the 
"barbarism" that "has prevailed in the darkest region of Africa" (Pleasant 1893, 95-96). White supremacy, in other words, was most appropriately secured by a liberal adherence to due process and the rule of law. Such critiques of lynching were typically accompanied by calls to bolster the state's capacity to punish. Indeed, some reformers even recommended that rape be tried in special courts, "where the guilty could be executed speedily and appeals could be limited" (Link 1997, 61).

By the time of the horrific "blowtorch lynching" of Roosevelt Townes and Robert McDaniels in Duck Hill, Mississippi, in 1937-regularly cited as the last public spectacle lynching in American history-the legal and political landscape had shifted significantly in segregationists' favor. When Henry Smith was murdered in 1893, most Southern states were only just beginning to see the political mobilizations that would usher in Jim Crow by establishing legal apartheid and entrenching black disfranchisement in state constitutions. But by the 1930s, all Southern state and many federal political institutions were collaborative with-if not outright controlled by-segregationist forces. During this period, lynching moved largely underground, taking shape as an increasingly clandestine form of terrorism, and an emergent set of carceral institutions took up the public function of maintaining the racial order. White mobs began to discover they could effectively bully courts into issuing death sentences against black victims by threatening to otherwise execute them themselves, inaugurating so-called "legal lynchings" (made famous with the Scottsboro boys; Ogletree 2006). Death sentences became typical for black men convicted of raping white women, and capital punishment proliferated throughout the South despite its coincident decline in many Northern states (Kaufman Osborn 2006). There were overall more capital executions in the 1930s than in any other decade in American history, and a striking disproportion of those executed were black Southerners (Banner 2003, 230). Police patrols began to appear with more frequency in the rural South; and, notwithstanding the support they received from some civil rights activists, professionalized police forces quickly assumed an integral role in enforcing racial hierarchy-as demonstrators in the Black Freedom Struggle would dramatize before the national public a generation later. To be sure, segregationists were not alone in their quest to strengthen the state's carceral machinery. Racial liberals, purportedly seeking to protect African Americans from wanton violence, would also have an important role to play (Murakawa 2014). Looking back upon this history from the vantage point of a twenty-first century marked by racialized mass incarceration and widespread police violence should render us wary of perspectives that would reduce the phenomenon of lynching to an insufficient respect for legal authority, and which in turn would prescribe simplistic "law and order" solutions.
The decline of lynching might thus be understood as, in part, a consequence of Jim Crow's success. ${ }^{13}$ Since lynchings were always tools of terror, their conspicuous decline can be grasped as a result of white supremacy's astounding victory in its long march through the institutions: as enforcing the color line fell under the prerogative of the state, the extra-legal terror of lynching was increasingly seen to be excessive and unnecessary. ${ }^{14}$ However, the disappearance of spectacle lynchings in particular was the outcome not only of capturing institutionalized power, but of having effectively reshaped the nation's political imaginary. ${ }^{15}$ With white supremacy firmly entrenched on the national agenda, the segregationist regime could forego the ritualized violence that had laid its foundations.

This history helps to illuminate the persistence of antiblack violence into the present. If the formation of American peoplehood is historically entwined with racialized violence, then vigilante slayings of black men-such as Yusef Hawkins (1989), James Byrd Jr. (1998), and Trayvon Martin (2012) - appear less an aberration from, and more a disturbing feature of, U.S. democracy (Zamalin 2017, 85-86; this is consistent with an understanding of the U.S. as a herrenvolk democracy, Olson 2004). A similar point may be made of the police killing of unarmed black people that has motivated the emergence of \#BlackLivesMatter. Despite the real achievements of the Black Freedom Struggle, the racialized polity built in the first half of the twentieth century has not simply persistedit has been institutionally fortified with the rise of the carceral state. Thus, far from disappearing, anti-black violence has been normalized as part of the ordinary operation of criminal justice: African-Americans make-up a mere 13\% of the population but comprise $34 \%$ of the nation's incarcerated population, including a full $43 \%$ of death row inmates (Equal Justice Initiative 2017, 21). These forms of contemporary racial violence may be less visible, but they are more pervasive and perhaps more insidious.

In a belated effort to respond to the United States' troubled history of racial violence, in 2018 the Senate finally passed, for the first time, a bill declaring lynching a federal crime. ${ }^{16}$ The House has recently approved a companion bill, which is expected to be signed into law this year. The new anti-lynching law was proposed on the Senate floor with reference to the recent surge in raciallymotivated hate crimes, and the bill's text begins with an explicit acknowledgment of the historical importance of lynching to American racism. This is a significant development. However, as this article has shown, lynching must be understood not only as "the ultimate expression of racism ... following Reconstruction" (as the bill puts it, S. 488, 2019), but as a practice that performed essential political work. The challenge today is therefore not only to acknowledge lynching's historical centrality, but to identify and confront the various practices by which racialized peoplehood is forged and reproduced 
in the present. Consider two examples. Beyond the racial mechanics of the carceral state analyzed earlier, the current moment is likewise marked by practices of racialized public violence-e.g., white supremacist mass shootings such as those at the AME Church in Charleston, SC (2015), the Tree of Life Synagogue in Pittsburgh, PA (2018), and the Walmart in EL Paso, TX (2019) — which may seem to herald a new dawn for the murderous politics of white sovereignty, this time framed as a reaction to demographic change (i.e., the Great Replacement). In a slightly different vein, contemporary deployments of state power, often theatrical and deeply racialized (e.g., the militarization of the border, draconian migrant detention, the ban on Muslim entry), might be seen as offering a virtual renewal of collective white sovereignty through less directly lethal means (Anker and Youmans 2017).

Agonistic democrats have turned to extra-institutional popular politics as a vital and potentially emancipatory alternative to purely procedural and juridified accounts of democracy; but they have done so only one-sidedly. I build on the insights of agonistic democratic theory but seek to correct for this lacuna by providing an account of the "dark side" of popular politics as exemplified in spectacle lynchings. Without denying the emancipatory promise latent in the notion of the people, I have shown that the language of peoplehood and popular sovereignty is not immune to counterrevolutionary cooptation. Indeed, the foregoing suggests that the politics of white supremacy might best be understood not as a project antithetical to the idiom of popular agency and authority but as a particular modality within it: white supremacy is an identity politics of the people. This insight need not inspire demotic skepticism. Rather, it might guide us in setting new priorities for democratic theory. For instance, rather than judging claims to speak in the people's name solely on the grounds of validity or felicity-that is, according to whether they appear to give "authentic" voice to popular desires-we might instead consider how such claims envision and fashion the demos. As I have shown, the dilemmas associated with how the demos is imagined - and through what practices it is to be made manifest-constitute a political problem of the first order. Attending more closely to the motley legacy of popular politics might in turn serve as a useful starting point for developing the tools necessary to critically evaluate the competing claims to popular authority that define our turbulent present-whether issued by state institutions, "populist" politicians, insurgent social movements, or the street demonstrations of a resurgent far right.

\section{Notes}

1 On the connection between spectacular violence and the imagination see Winter 2018, 34-65.

2 Hartman 1997 acknowledges the importance of spectacular violence to the production of racial subjugation but aims to displace it by directing attention to how the terror of slavery permeated even seemingly quotidian scenes of enjoyment and amusement. She argues that in representing scenes of extraordinary violence, scholars tend to enlist their audience as spectators to that violence and thereby reproduce the relations of subordination inaugurated in them. The present article is an effort to grapple with the politics of subjection and spectatorship in public lynchings. The hope is that in doing so we may develop the conceptual tools that will enable us to look critically at the lynch mob, rather than being destined to always look with them.

3 Some notable exceptions to this general trend include Duong 2017; Kirkpatrick 2008; Olson 2004. Historians of lynching have of course taken much less sanguine views of "popular" politics, though they have not framed their contributions with reference to the theory of popular sovereignty; Belew 2014; Pfeifer 2011.

4 In the past several years there has been an explosive growth of academic literature on populism. While many of the parties and figures labeled populist combine reactionary politics with an avowed commitment to popular sovereignty, they nonetheless differ in quite significant ways from the phenomenon of lynching, which was extra-institutional (rather than anchored in the electoral sphere) and considerably less leadercentric; Müller 2016; Urbinati 2019.

5 This account of popular constituent power thus differs from dominant teleological conceptions, such as Kalyvas 2005, 233: "the constituent sovereign in a strict sense is a purely teleological concept in that it realizes itself by creating novel constitutional norms . . . the telos of the constituent power, its true finality, is manifested solely through the higher laws it originally creates or subsequently amends."

6 For a critical assessment of the limitations of this theory for understanding slavery, among other issues, see Markell 2008.

7 Though the form of the relationship of domination is homologous, Wells nonetheless notes that the consequences of the regimes differed significantly.

During the slave regime, the Southern white man owned the Negro body and soul. It was to his interest to dwarf the soul and preserve the body. Vested with unlimited power over his slave, to subject him to any and all kinds of physical punishment, the white man was still restrained from such punishment as tended to injure the slave by abating his physical powers and thereby reducing his financial worth. While slaves were scourged mercilessly, and in countless cases inhumanly treated in other respects, still the white owner rarely permitted his anger to go so far as to take a life, which would entail upon him a loss of several hundred dollars. The slave was rarely killed, he was too valuable; it was easier and quite as effective, for discipline or revenge, to sell him 'Down South.' But emancipation came and the vested interests of the white man in the Negro's body were lost ... with freedom, a new system of intimidation came into vogue. The Negro was not only whipped and scourged; he was killed. 
According to Wells, black life was held to be more disposable under Jim Crow than under slavery. Therefore, though the structure of domination remained the same, the empirical frequency of killing increased; Wells 2014, 221.

8 Watson, a zealous white supremacist by the early twentieth century, would likewise agree with Schmitt that "democracy requires ... first homogeneity and second - if the need arises - elimination or eradication of heterogeneity"; 1988, 6.

9 Daniel Kato has provided one explanation of the vexing legal status of lynching by developing a theoretical framework he dubs "constitutional anarchy," which he argues can help tease "out how legalism can sometimes enable lawlessness." According to Kato, constitutional anarchy refers to a relatively stable arrangement of control that was predicated on how the three federal branches of government handled issues that each dreaded publicly, but approved of privately, thereby allowing the federal government the means by which it could deflect accountability while retaining authority ... [it] reveals how the separation of power not only divides responsibility but can also obscure it." (Kato 2015, 2)

10 My use of the language of retribution consciously departs from the standard philosophical conception of "retributive justice," which always includes proportionality as a requirement; Walen 2016. As I have argued earlier, lynching did not primarily aim at establishing justice, even in a retributive sense.

11 It bears noting that Foucault never offered an analysis of popular sovereignty-he always theorized sovereignty as an attribute of the state. For a critical analysis of this point see Olson, 2016, 51.

12 In a similar vein, Obert and Mattiacci 2018 find that vigilantism has historically served as a practice of collective identity formation amid conditions of social ambiguity.

13 It would not be right to claim that it was the sole cause, however. Activism also played an important role, as demonstrated in recent work, including Francis 2014 and Weaver 2019

14 For arguments supporting the view that state power supplanted lynching, see Clarke 1998 and Epperly et al. 2019. For a critique of the "substitution model," in which state execution is said to directly replace lynching, see Beck, Massey, and Tolnay 1989.

15 Smångs 2016 suggests that spectacle lynchings began to decline because, by the early 1910s, "the foundational racial categories, boundaries, and identities" of Jim Crow had been "firmly established" (1362).
16 The Dyer Anti-Lynching Act had previously passed the House in 1922, but no companion legislation was ever able to overcome Senate filibuster.

\section{References}

Abizadeh, Arash. 2012. "On the Demos and Its Kin: Nationalism, Democracy, and the Boundary Problem." American Political Science Review 106(4): 867-82.

Agamben, Giorgio. 2005. State of Exception. Chicago: University of Chicago Press.

Allen, Danielle S. 2006. Talking to Strangers: Anxieties of Citizenship since Brown v. Board of Education. Chicago: University of Chicago Press.

Allen, James. 2000. Without Sanctuary: Lynching Photography in America. 10th ed. Santa Fe, NM: Twin Palms Publishers.

Anker, Elisabeth R. and William L Youmans. 2017. "Sovereign Aspirations: National Security and Police Power in a Global Era." Theory \& Event 20(1): 3-18.

Balfour, Lawrie. 2011. Democracy's Reconstruction: Thinking Politically with W.E.B. Du Bois. New York: Oxford University Press.

_ 2015. "Ida B. Wells and 'Color Line Justice': Rethinking Reparations in Feminist Terms." Perspectives on Politics 13(3): 680-96.

Banner, Stuart. 2003. The Death Penalty: An American History. Cambridge, MA: Harvard University Press.

Beck, E. M., James L. Massey, and Stewart E. Tolnay. 1989. "The Gallows, the Mob, and the Vote: Lethal Sanctioning of Blacks in North Carolina and Georgia, 1882 to 1930." Law \& Society Review 23(2): 317-31.

Belew, Kathleen. 2014. "Lynching and Power in the United States: Southern, Western, and National Vigilante Violence." History Compass 12(1): 84-99.

Benjamin, Walter. 1986. Reflections: Essays, Aphorisms, Autobiographical Writings. Ed. Peter Demetz. New York: Schocken.

- 2019. Illuminations: Essays and Reflections. New York: Mariner Books.

Berg, Manfred. 2015. Popular Justice: A History of Lynching in America. Reprint. Lanham, MD: Rowman \& Littlefield Publishers.

Bonner, Robert E. 2009. "Proslavery Extremism Goes To War: The Counterrevolutionary Confederacy and Reactionary Militarism." Modern Intellectual History 6 (2): 261-85.

Bourke, Richard, and Quentin Skinner, eds. 2017. Popular Sovereignty in Historical Perspective. Reprint. Cambridge: Cambridge University Press.

Brendese, P.J. 2017. "Worlds Neither New Nor Brave: Racial Terror in America." Theory \& Event 20(1): 24-43. Bromell, Nick. 2013. The Time Is Always Now: Black Thought and the Transformation of US Democracy. New York: Oxford University Press. 
Brundage, William Fitzhugh. 1993. Lynching in the New South: Georgia and Virginia, 1880-1930. Champaign: University of Illinois Press.

Buckser, Andrew S. 1992. "Lynching as Ritual in the American South.” Berkeley Journal of Sociology 37: 11-28.

Canovan, Margaret. 2005. The People. Cambridge, MA: Polity.

Carr, Jesse. 2016. “The Lawlessness of Law: Lynching and Anti-Lynching in the Contemporary USA." Settler Colonial Studies 6(2): 153-63.

Clarke, James W. 1998. "Without Fear or Shame: Lynching, Capital Punishment and the Subculture of Violence in the American South." British Journal of Political Science 28(2): 269-89.

Cutler, James Elbert. 1905. Lynch-Law: An Investigation into the History of Lynching in the United States. New York: Longmans, Green, and Co.

Douglass, Frederick. 1892. "Lynch Law in the South." North American Review 155(428): 17-24.

Dray, Philip. 2003. At the Hands of Persons Unknown: The Lynching of Black America. Reprint. New York: Modern Library.

Dred Scott v. Sandford, 60 U.S. 393 (1856).

Du Bois, W.E.B. 2014. Dusk of Dawn. Eds. Henry Louis Gates and Kwame Anthony Appiah. New York: Oxford University Press.

- 1998 [1935]. Black Reconstruction in America, 1860-1880. Ed. David Levering Lewis. New York: Free Press.

Duong, Kevin. 2017. "The People as a Natural Disaster: Redemptive Violence in Jacobin Political Thought." American Political Science Review 111(4): 786-800.

Epperly, Brad, Christopher Witko, Ryan Strickler, and Paul White. 2019. "Rule by Violence, Rule by Law: Lynching, Jim Crow, and the Continuing Evolution of Voter Suppression in the U.S." Perspectives on Politics. https://doi.org/10.1017/S1537592718003584.

Equal Justice Initiative. 2017. "Lynching in America: Confronting the Legacy of Racial Terror" $3 \mathrm{~d}$ ed. Montgomery, AL: Equal Justice Initiative.

Espejo, Paulina Ochoa. 2011. The Time of Popular Sovereignty: Process and the Democratic State. University Park, PA: Penn State University Press.

Euben, Roxanne L. 2017. "Spectacles of Sovereignty in Digital Time: ISIS Executions, Visual Rhetoric and Sovereign Power." Perspectives on Politics 15(4): 1007-33.

Feimster, Crystal N. 2011. Southern Horrors: Women and the Politics of Rape and Lynching. Cambridge, MA: Harvard University Press.

Foucault, Michel. 1995. Discipline \& Punish: The Birth of the Prison. New York: Vintage Books.
Francis, Megan Ming. 2014. Civil Rights and the Making of the Modern American State. Cambridge: Cambridge University Press.

Frank, Jason. 2010. Constituent Moments: Enacting the People in Postrevolutionary America. Durham, NC: Duke University Press.

Friedman, Ryan Jay. 2007. "Between Absorption and Extinction: Charles Chesnutt and Biopolitical Racism." Arizona Quarterly: A Journal of American Literature, Culture, and Theory 63(4): 39-62.

Garland, David. 2005. "Penal Excess and Surplus Meaning: Public Torture Lynchings in TwentiethCentury America." Law \& Society Review 39(4): 793-833.

Gooding-Williams, Robert. 2011. In the Shadow of Du Bois: Afro-Modern Political Thought in America. Reprint. Cambridge, MA: Harvard University Press.

Habermas, Jürgen. 1994. "Human Rights and Popular Sovereignty: The Liberal and Republican Versions." Ratio Juris 7(1): 1-13.

Hale, Grace Elizabeth. 1999. Making Whiteness: The Culture of Segregation in the South, 1890-1940. New York: Vintage.

Hanchard, Michael. 2010. "Contours of Black Political Thought: An Introduction and Perspective." Political Theory 38(4): 510-36.

Hartman, Saidiya V. 1997. Scenes of Subjection: Terror, Slavery, and Self-Making in Nineteenth-Century America. New York: Oxford University Press.

Honig, Bonnie. 2007. "Between Decision and Deliberation: Political Paradox in Democratic Theory." American Political Science Review 101(1): 1-17.

- 2011. Emergency Politics: Paradox, Law, Democracy. Reprint. Princeton, NJ: Princeton University Press.

Hooker, Juliet. 2019. Theorizing Race in the Americas: Douglass, Sarmiento, Du Bois, and Vasconcelos. Reprint. New York: Oxford University Press.

Justice for Victims of Lynching Act of 2019, S.488, 116th Congress (2019).

Kalyvas, Andreas. 2005. "Popular Sovereignty, Democracy, and the Constituent Power." Constellations 12(2): 223-44.

Kato, Daniel. 2015. Liberalizing Lynching: Building a New Racialized State. New York: Oxford University Press.

Kaufman Osborn, Timothy. 2006. "Capital Punishment as Legal Lynching?" In From Lynch Mobs to the Killing State: Race and the Death Penalty in America, eds. Charles J. Ogletree Jr. and Austin Sarat, 21-54. New York: New York University Press.

Kertzer, David I. 1989. Ritual, Politics, and Power. New Haven, CT: Yale University Press.

Kirkpatrick, Jennet. 2008. Uncivil Disobedience: Studies in Violence and Democratic Politics. Princeton, NJ: Princeton University Press. 
Kotef, Hagar. 2019. "Violent Attachments." Political Theory 48(1): 4-29.

Lee, Daniel. 2016. Popular Sovereignty in Early Modern Constitutional Thought. New York: Oxford University Press.

Lefort, Claude. 1991. Democracy and Political Theory. Cambridge, UK: Polity.

Link, William A. 1997. The Paradox of Southern Progressivism, 1880-1930. Chapel Hill: University of North Carolina Press.

MacLean, Nancy. 1991. "The Leo Frank Case Reconsidered: Gender and Sexual Politics in the Making of Reactionary Populism." The Journal of American History 78(3): 917-48.

Markell, Patchen. 2008. "The Insufficiency of NonDomination." Political Theory 36(1): 9-36.

Mathews, Donald. 2002. "The Southern Rite of Human Sacrifice." Black History Bulletin 65(3): 20-47.

Mathews, Donald G. 2017. At the Altar of Lynching: Burning Sam Hose in the American South. Cambridge: Cambridge University Press.

Mbembé, J.-A. 2003. "Necropolitics." Trans. Libby Meintjes. Public Culture 15(1): 11-40.

McCarthy, Thomas. 2009. Race, Empire, and the Idea of Human Development. New York: Cambridge University Press.

McKnight, Utz. 2013. Race and the Politics of the Exception: Equality, Sovereignty, and American Democracy. New York: Routledge.

Mills, Charles W. 1999. The Racial Contract. Ithaca, NY: Cornell University Press.

Morgan, Edmund S. 1989. Inventing the People: The Rise of Popular Sovereignty in England and America. Revised ed. New York: W.W. Norton \& Company.

Müller, Jan-Werner. 2016. What Is Populism? Philadelphia: University of Pennsylvania Press.

Murakawa, Naomi. 2014. The First Civil Right: How Liberals Built Prison America. New York: Oxford University Press.

Näsström, Sofia. 2007. "The Legitimacy of the People.” Political Theory 35(5): 624-58.

Obert, Jonathan and Eleonora Mattiacci. 2018. "Keeping Vigil: The Emergence of Vigilance Committees in Pre-Civil War America." Perspectives on Politics 16(3): 600-16.

Ogletree, Charles J. 2006. "Making Race Matter in Death Matters." In From Lynch Mobs to the Killing State: Race and the Death Penalty in America, eds. Austin Sarat and Charles J. Ogletree, 55-95. New York: New York University Press.

Olson, Joel. 2004. Abolition of White Democracy. Minneapolis: University of Minnesota Press.

Olson, Kevin. 2016. Imagined Sovereignties: The Power of the People and Other Myths of the Modern Age. New York: Cambridge University Press.
Patterson, Orlando. 1982. Slavery and Social Death: A Comparative Study. 1st edition. Cambridge, MA: Harvard University Press.

Patterson, Orlando. 1999. Rituals Of Blood: The Consequences Of Slavery In Two American Centuries. Revised ed. New York: Civitas Books.

Pettit, Philip. 1996. "Freedom as Antipower." Ethics 106 (3): 576-604.

- 1999. Republicanism: A Theory of Freedom and Government. Oxford: Oxford University Press.

Pfeifer, Michael J. 2006. Rough Justice: Lynching and American Society, 1874-1947. Reprint. Urbana: University of Illinois Press.

- 2011. The Roots of Rough Justice: Origins of American Lynching. Urbana: University of Illinois Press.

Pleasant, James. 1893. "The Facts in the Case of the Horrible Murder of Little Myrtle Vance and Its Fearful Expiation at Paris, Texas, February 1st, 1893.” Library of Congress, Washington, D.C. 20540 USA. https:// lccn.loc.gov/01000615.

Rogers, Melvin L. 2012. "The People, Rhetoric, and Affect: On the Political Force of Du Bois's The Souls of Black Folk." American Political Science Review 106(1): 188-203.

Roosevelt, Theodore 1923 The Works of Theodore Roosevelt. Memorial ed. Vol. 17. New York: C. Scribner's Sons.

Rushdy, Ashraf H. A. 2014. American Lynching. New Haven, CT: Yale University Press.

Schmitt, Carl. 1988. Crisis of Parliamentary Democracy. Cambridge, MA: The MIT Press.

- 2006. Political Theology: Four Chapters on the Concept of Sovereignty. Ed. Tracy B. Strong. Chicago: University of Chicago Press.

Skinner, Quentin. 2012. Liberty before Liberalism. Reprint. Cambridge: Cambridge University Press.

Smångs, Mattias. 2016. "Doing Violence, Making Race: Southern Lynching and White Racial Group Formation." American Journal of Sociology 121(5): 1329-74.

Squires, David. 2015. "Outlawry: Ida B. Wells and Lynch Law." American Quarterly 67(1): 141-63.

Tolnay, Stewart E. and E. M. Beck. 1995. A Festival of Violence: An Analysis of Southern Lynchings, 1882-1930. Urbana: University of Illinois Press.

Tuck, Richard. 2016. The Sleeping Sovereign: The Invention of Modern Democracy. Reprint. Cambridge: Cambridge University Press.

Turner, Jack. 2012. Awakening to Race: Individualism and Social Consciousness in America. Chicago: University of Chicago Press.

Urbinati, Nadia. 2019. "Political Theory of Populism." Annual Review of Political Science 22(1): 111-27.

Valdez, Inés. 2020. "Reconceiving Immigration Politics: Walter Benjamin, Violence, and Labor.” American Political Science Review 114(1): 95-108. 
Waldrep, Christopher. 2002. The Many Faces of Judge Lynch: Extralegal Violence and Punishment in America. New York: Palgrave Macmillan.

- ed. 2006. Lynching in America: A History in Documents. New York: New York University Press.

Walen, Alec. 2016. "Retributive Justice.” In The Stanford Encyclopedia of Philosophy, ed. Edward N. Zalta. Metaphysics Research Lab, Stanford University. (https://plato.stanford.edu/archives/win2016/entries/ justice-retributive/).

Weaver, Michael. 2019. “'Judge Lynch' in the Court of Public Opinion: Publicity and the De-Legitimation of Lynching." American Political Science Review 113(2): 293-310.

Wells, Ida B. 2014. The Light of Truth: Writings of an AntiLynching Crusader. Eds. Mia Bay and Henry Louis Gates. New York: Penguin Classics.

Wilson, Bee. 2013. "Counter-Revolutionary Thought." In The Cambridge History of Nineteenth-Century
Political Thought. Cambridge: Cambridge University Press.

Winter, Yves. 2018. Machiavelli and the Orders of Violence. Cambridge: Cambridge University Press.

Wood, Amy Louise. 2011. Lynching and Spectacle: Witnessing Racial Violence in America, 1890-1940. Chapel Hill: University of North Carolina Press.

Woodward, C. Vann. 2001. The Strange Career of Jim Crow. Commemorative edition. Ed. William S. McFeely. First published 1955. Oxford : Oxford University Press.

Wright, Richard. 2007 [1945]. Black Boy: A Record of Childhood and Youth. Anniversary ed. New York: Harper Perennial Modern Classics.

Zamalin, Alex. 2017. Struggle on Their Minds: The Political Thought of African American Resistance. New York: Columbia University Press. 